\title{
3-2 自動車における画像処理
}

\section{1. ま え がき}

自動車の知能化は, エンジンやシャシ系の制御，そ して, 経路案内や地眓情報処理など, 半導体技術と共 に, 急速に進展してきだ1).これらは, 快適でやさし く運転できる車を目指してきたものである，昨今で は, 交通安全, 渋滞問題, 地球環境保護など, 新たな 課題が話題になってきている。これらに対応するに は, 個々の車にさらなる高知能化が必要とされると共 に，道路側のインフラストラクチャを含めた交通シス テム全体の整備も重要で, 国内外で各種のシステムの 研究が進行中である2).

高知能自動車の究極は自動操縦であるが，それに至 る過程で, 安全を意識した各種警報装置や, 運転者に アドバイスする装置が考えられる，人が車を運転する 時, 必要な情報のほとんどを視覚に頼っているといわ れ，したがって，人に代わる知能を車に持たせるとす ると, 目に当たる画像処理システム (マシンビジョン) が最も大きな役割を担うことは, 容易に想像される.

本稿では, 車載のためのマシンビジョンについて, まず処理対象を抽出し, 自動車固有の画像処理の課題 について述べる.そして, 研究事例として, 高速道路 の実時間白線認識と処理ハードウエアについて，筆者 らの取り組みを紹介する。なお，米国における $\mathrm{ALV}$ (Autonomous Land Vehicle) プロジェクトをはじめ とする国内外の自動操縦車や, 移動ロボットの研究動 向については, 文献 3)〜8)に詳しいので譲りたい.

\section{2. 自動車用環境認識}

自動車用マシンビジョンの応用システムの概念図を 図 1 に示す，運転者の行っている処理に対応させたも のである。まず画像から様々な対象物を認識し, 認識 結果の統合化や時間変化などから自動車のおかれてい る状況を判断する。そして, 状況に応じて車両制御を

$\dagger$ 日産自動車株式会社 総合研究所

"Image Processing for Automotive Applications" by Kazunori Nohsoh (Nissan Research Center, Nissan Motor Co., Ltd., Yokosuka)
行ったり，運転者に警報やアドバイスを与える。

マシンビジョンの認識対象として最も重要なのは, 周囲の状況を認識する環境認識である．図 2 に，周囲 環境認識の認識対象として, 画像認識で得られる直接 的な情報と判断項目の例を示す.

認識対象を時間変化の大きさによって分類したのが 図 3 である．時間変化とは，本来の時間の流れによっ て変化するものと, 車両が動くことでシーンが変化す るものとの両方を考慮する．時間的に大きく変化しな いもの，これは地域的なものが多いが，これらについ ては路車間通信などのインフラで対応することを考え れば，車両のごく近傍の，変化の激しい対象が重要な 認識対象といえる。なお，例えば車々間通信や歩行者 と車との通信，道路の誘導ケーブルなどの，画像処理 以外の手段も考えられるが, 普及性や設置性の問題や 技術的課題も残されている。ここでは，自動車周囲の 環境として, 道路境界, 他車, 歩行者, 静止障害物な どをマシンビジョンの対象と考える.

処理の結果としては,

(a) 対象物の認識

（b）対象物までの距離や方位の計測

の 2 つが含まれる。例えば, 単に先行車の認識といつ ても，(1)高さのある障害物として検出（距離や相対速 度を出力, 衝突防止), (2)車であることを認識(車とい う認識結果と距離などを出力, 前車追従), (3)ウィン カやブレーキランプの認識（先行車の動きや意図の予 測，自動操縦）などのレベルが考えられる.

また, 道路端やレーンマーキング(以下白線と略す) の認識では, (1)道路端や車線の認識, (2)道路に対する 自車位置や姿勢の計測, (3)前方のカーブや勾配の予 測，といったレベルが考えられる．

走行道路によるレベルも考えられる．例えば，(1)高 速道路や自動車専用道路に限定，(2)一般の舗装路，(3)

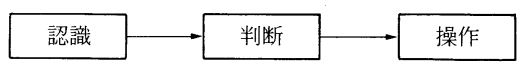

図 1 自動車用画処理の応用

テレビジョン学会誌 Vol. 46, No. 8, pp. 978〜984（1992） 


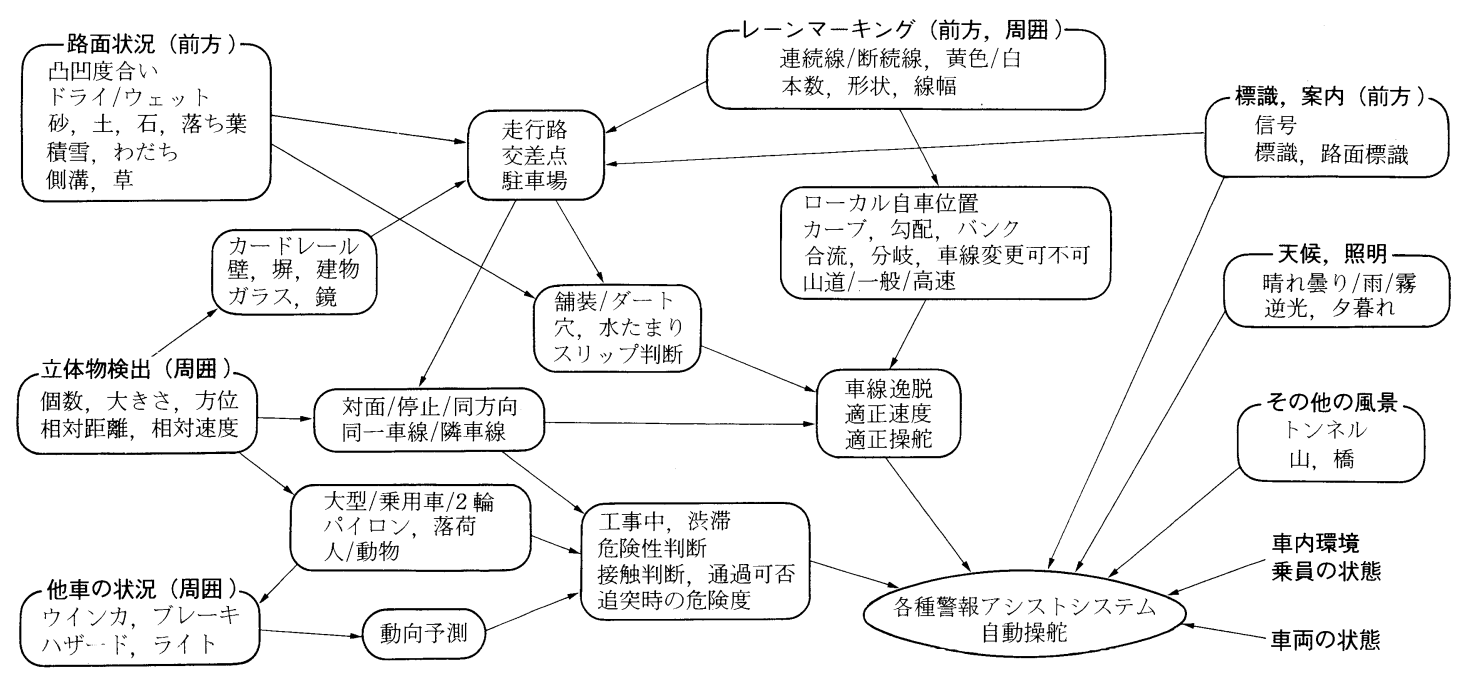

図 2 自動車用画像処理の処理対象

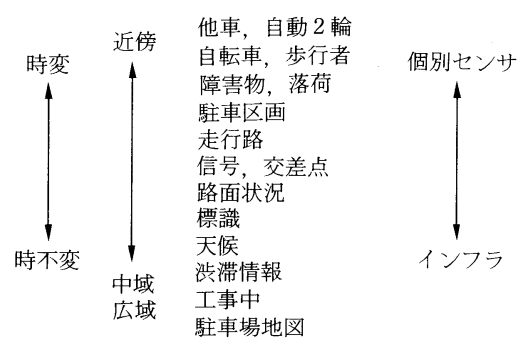

図 3 車両周囲の環境認識

未舗装道路，などである。

このように, 応用によって要求レベルが変わり, 逆 に, 実現レベルから応用システムを段階的に発展させ ることも考えられる。

\section{3. 自動車の画像処理の諸課題}

\section{1 自動車固有の問題点}

自動車用のマシンビジョンが対象とするシーンは, 屋外で昼夜天候を問わず，非常に広い地域を移動する ため, 例えば工場の生産現場に導入されるそれとは, 以下の点で大きく異なる。

（a）照明環境が大きく変化する。晴雨, 昼夜, 逆 光，トンネルなどである.

（b）広範囲を見る必要がる．車両前方のみならず 側方や後方も含まれる。

（c）カメラも動き, かつ, 他車や歩行者など処理 対象も動く場合がある. 走行速度のみならず，
カメラの俯角（ピッチ角）なども変化する.

（d）対象物は，そ机自体様々な形状や色を有し， また，動きや照明によっても見え方が変化す る。車種による違いや後面や側面でも見え方が 異なる. 歩行者も形状変化が大きい.

（e）背景が複雑で予期できない.

などである。また，処理速度も課題である。このほか にも, コストの問題やユーザとのインタフェースなど に，民生用としての課題がある．

このように, 照明条件や処理対象が多彩な環境下 で，正確に(頑健かつ精度良く), 高速に実行され，低 コストなシステムでなければならない。

これらは,

(a) 入力デバイスやセンサの課題

（b）処理アルゴリズムや処理装置の課題 の両方の課題に及ぶ.

\section{2 入カデバイスやセンサの課題}

天候や照明環境に対する処理の頑健性は，入力デバ イスの問題によるところが大きい．現在の CCD カメ ラではダイナミックレンジが不足で，1枚の画像に日 向と日陰が含まれると, 両方の領域で鮮明な画像化を 行うのは難しい，画角の問題は，NTSC 方式にとら われなければ解決は可能であろう。移動ロボットでは ミラーを使って全方位のシーンを 1 枚の画像に入力す ることも研究されている9 .

いわゆる機械の目としてのセンサは，可視光 CCD である必要は特にない. 遠赤外光のほうが歩行者や他 車の検出に向くとされる ${ }^{10)}$. また，レーザレンジファ 
インダ11)のようなアクティブな 3 次元センサは，天 候や照明の影響が少なく, 障害物や路面段差の検出に 有効である。いずれも低コスト化は大きな課題であ る、レーザレンジファインダは，一般にはスポット光 をスキャンニングするため, 2 次元の距離画像を入力 するには時間がかかるが, センサと信号処理部をアレ イ化することにより高速化する研究も報告されてい $3^{12)}$.

\section{3 処理アルゴリズムと処理装置}

ここでは, 対象物の認識と距離などの計測に分け て，アルゴリズムの諸課題を述べる (図 4 参照).

\section{（1）認 識}

物体の認識は, 背景や物体の重なりから, 認識すべ き物体を切り出すことが, 最も重要かつ困難な課題で ある、例えば，画像から白線を認識しょうとすると き, 影や路面の污れのみならず, 路面上の表示（横断 歩道や制限速度など）もノイズとなりうる。

一般に物体の切り出しには, 色の利用, 形状情報の 利用, 動きの利用, などが考えられる。しかしなが ら, 前述の自動車固有の問題点から,

(a) 色の利用につては, 可視光域では様々な車体 色や衣服が存在するため, 赤外域も含めたマル チバンドカメラが必要.

（b）形状も，車種による小変形や大型車・小型車 など, また, 歩行者の場合は時間的に形状が変 化するため, 何らかの特殊なモデル化手法が必 要.

（c） カメラが固定の場合, 動く物体は動画像処理 で切り出せるが ${ }^{13)}$, 自車も動くため正確なカメ ラの動き計測が必要.

と, 問題点は多い.

(2) 計 測

距離や道路端の位置などの 3 次元計測については, 単眼, 多眼ステレオ, 前述の 3 次元センサの利用, そ して,これらや他のセンサとのフュージョン ${ }^{14)}$ が考 えられる。

道路端は平行であるという拘束条件を使えば，単眼

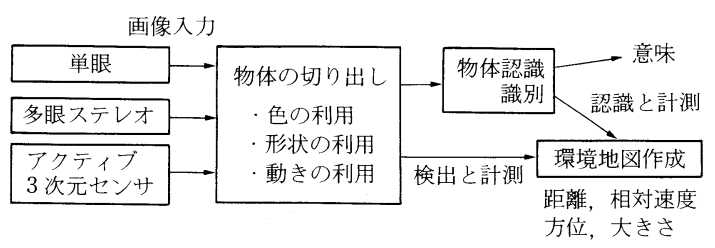

図 4 マシンビジョンシステム
でも道路の 3 次元形状を計測することは可能であ $3^{15) 16)}$. また, 路面の形状が既知で路面上の物体が切 り出されていれば, その物体までの距離を知ることも できる ${ }^{17)}$. 多眼ステレオは一般的には画像間の対応付 けが課題である. 路面上の物体検出に限定したり ${ }^{18)}$,

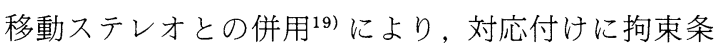
件を付加することができる．ステレオ方式の障害物検 出の場合, エッジでなく面として有無判断が必要であ る20). 自律移動ロボットに扔ける移動ステレオでは, アクティブビジョンのように，自車の動きを制御しな がら認識することも可能である ${ }^{21)}$.しかし，自動車の 場合は自車の正確な動きの計測22)がまず必要であ る.

3 次元センサは距離画像が得られるので, 距離が直 接求められるのみならず, 路面のような水平面から障 害物や壁などの高さのある物体を切り出すのに, 非常 に有効である。

\section{(3) 処理装置}

車両近傍の環境認識では, 例えば障害物の発見は速 ければ速いほど良い，白線に沿って自動走行する場合 のレーン認識の処理時間は 0.1 秒以内といわれてい $ろ^{23)}$.このように, 処理の実時間性が強く要求され, 専用画像処理装置 ${ }^{24)}$ が必要である。ただし, 過去数 年のマイクロプロセッサの高速化が，そのまま将来も 進展すれば，いずれ解決されるとも考えられる25).

以上のように，アルゴリズムについての課題が最も 困難である.2 章で述べたように認識レべルを段階的 に設定し，それぞれに適した処理を研究しながら，着 実に進めていく必要があると感じる。

\section{4. 研 究 事 例}

自動車用画像処理の第一歩として, 筆者らは 2 車線 高速道路の白線の実時間認識を行った ${ }^{26)}$.ノイズや途 切れ線汶対する処理の正確性と, 処理の高速性の両立 を㸚らいとするものである，処理手法と実行ハードウ エアについて簡単に紹介する.

\section{1 道路画像処理手法}

処理の流れを図 5 に示す. $256 \times 240$ 画素のモノク 口濃淡画像を入力し, 後述の高速画像処理装置を用い てフレームレート (33 ms/画面)で, 3 本の白線を直線 として求める.さらに, カーブ度計測と自車線前方の 先行車検出を行った。

(1) 前処理

前処理として, 濃度勾配によるエッジ方向を求め る. 白線の画像上での傾き角の条件を考慮に入れた検 出が可能となり，ノイズに強い処理が期待できるから 


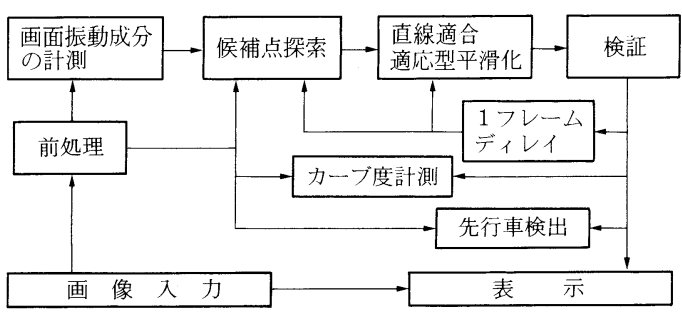

図 5 道路画像処理

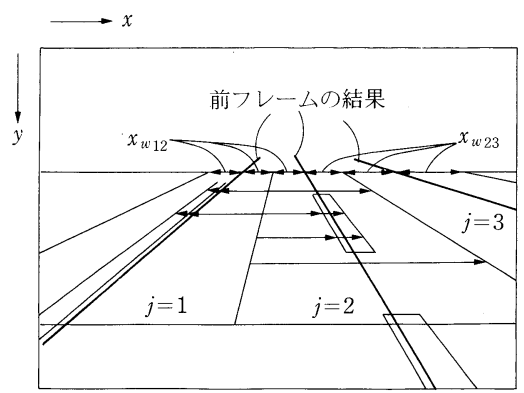

図 6 候補点の探索

である。

（2）画面振動成分の検出

車両が走行すると, 1 数 $\mathrm{Hz}$ で画面が上下に振動 する画像が得られる. 白線位置も上下に動くため, 後 の処理が簡便に行えるよう, まず画面振動を吸収す る. 車両が走行中でも, ガードレール上端や白線, 側 溝など, 車両の進行と平行に延びる線成分の, 画面上 での位置は見かけ上変化しないものと考えられる。よ って, このような点を何点か画像から抽出し, 連続す る 2 枚の画像間で $y$ 軸方向移動量を求めて平均化し, さらに時間積分すれば画面振動成分となる．以下の処 理は, 画像を $y$ 軸方向にこの量だけシフトして行 う.

\section{(3) 候補点探索}

画面振動が吸収された画像においては，白線は時間 的に緩やかに移動するものと考えられる。よって, 前 フレームの検出結果を参照しながら, 現時刻の画像を 以下のように処理する.なお, 直線は直線 $i$ と表し, $i$ は左側から順に $1,2,3$ とする.

1 フレーム前の結果に基づき, 3 本の直線それぞれ に対応する候補点の探索領域を設定し, 白線の候補点 を探索する(図6). 画像を $x$ 軸に沿って走査し, 直線 1 は右上がり $(\pi / 8 \sim 3 \pi / 8)$ で白線の右側のエッジ点, 直線 2 は $\pi / 6 \sim 5 \pi / 6$ 程度の傾きで走行車線内側, 直 線 3 は左上がり $(5 \pi / 8 \sim 7 \pi / 8)$ で白線の左側のエッジ 点を, それぞれ探索し座標を記憶する。

(4) 直線適合と適応型平滑化

3 組の候補点を対象にそれぞれ直線適合を行う。他 車や路面の污れ等，ノイズ成分に強くするために, Hough 変換のように最も多くの候補点を通る直線を 求める。また, 直線上に乗る候補点の数を, 確からし さ $p_{i}$ とする.

直線適合の結果と $p_{i}$ および前フレームの検出結果 に基づき， $p_{i}$ を時定数とする適応型平滑化を施す． $p_{i}$ が大きな值の時は今回の結果に大きな重みをかけて大 きく修正し, 逆に小さな値の時は前フレームの結果に
大きな重みをかけて少しだけ修正する。こうして，対 ノイズ性の他に，断続線や他車によって一部が隠され た白線など，線の途切れにも対処する。

(5) 検 証

3 本の線は互いに遠過ぎず近過ぎず，かつ未広がり の関係にあることなどの条件と， $p_{i}$ の大きさに基づ いて，エラーが起きた場合に回復を行う.

（6） カーブ度計測

高速道路ではカーブは緩やかであること，そして， 曲線より直線のようにパラメータが少ないほうがロバ ス卜な検出が行えることから, 白線は直線式で求め た。

求められた直線付近でエッジ点を再度探索し, 曲線 式をあてはめることにより, カーブ度を求めることが できる、いったん直線を求めているため, その近傍で 確かなエッジ点が探索できる．エッジ点に，

$$
x=a\left(y-y_{s}\right)+b /\left(y-y_{s}\right)+c
$$

を最小二乗法によってあてはめ, $a, b, c$ を求めれ ば， $b$ は曲率におよそ比例した值となる。なお，ys は消失点の $y$ 座標で, 直線検出結果から求められ る。

\section{（7）先行車検出}

あらかじめ車線が検出されるため, 自車線前方のみ の先行車を検出できる. 自車線領域について前処理画 像を走査し, エッジ点数が多く, かつ広く存在する領 域の有無を調べる。この領域がある時間連続して存在 する時, 先行車有りと判断する。なお，本手法による と, 路面上の影や文字なども検出される可能性があ る。

\section{2 高速画像処理装置}

本装置は, 新規開発されたアルゴリズムでも高速に 実行できる，汎用の画像処理装置を目指したものであ る ${ }^{27)}$. 大きさは約 $400 \mathrm{~mm}$ 立方である.

本装置の全体アーキテクチャを図 7 に示す. 


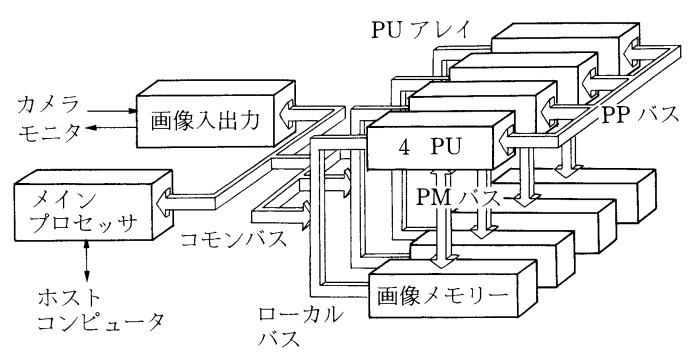

図 7 高速画像処理装置の全体構成

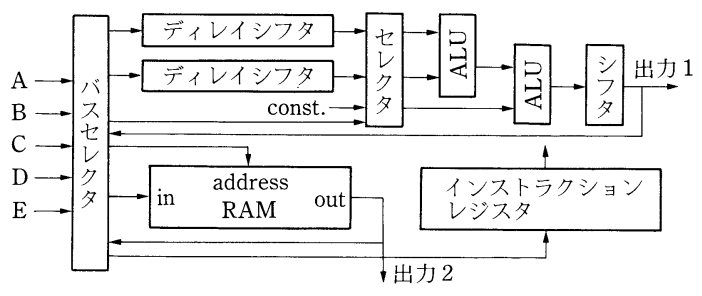

図 8 PUの内部構成

\section{(1) PUアレイ}

PUアレイは, PULSI 16 個とバスセレクタ, バッ ファなどより成る, 機能可変構造可変型パイプライン プロセッサである。できるだけ種々の前処理や特徵抽 出がビデオレート処理できるよう, 処理の柔軟性の向 上をねらいとする。

PUの内部構成を図 8 に示す.PUには内部機能と して, 2 つ ALU, 可変ディレイ, RAM などをも ち, 各インストラクションレジスタに命令をセットす ることによって, 機能を可変することができる. RAM は， 9 ビット × 512 ワードの容量をもち，アド レスやライト信号を制御することにより，1次元の LUT (ルックアップテーブル), 画像を順次走査した 時の 1 ラインディレイ (FIFOメモリー), 処理結果を 内蔵する RAM，などとして用いることができる。

$\mathrm{PU}$ の内部バス, PU 相互間のバス, PU や画像メ モリー間のバスとして, 多数のパイプラインバスを備 える。バスも各インストラクションレジスタに命令を セットすることで, 図9 に示すように様々な構造に可 変できる. 機能構造共に一度設定された命令は次に変 更するまで有効で, 命令セット後, 画像を走査しなが らデータを次々に入力していくことにより, 同一の演 算が画面全体に施される。

(2) メインプロセッサ

MPU (メインプロセッサ) は, マイクロプログラム 式プロセッサで構成した。装置全体の制御の他に, 主

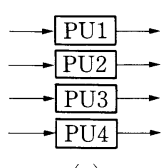

(a)

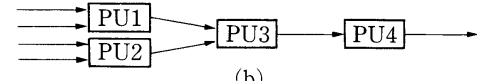

(b)

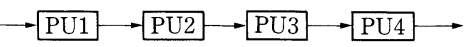

(c)

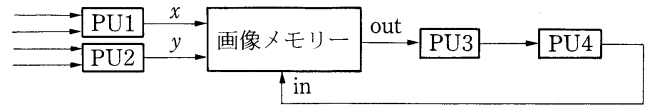

(d)

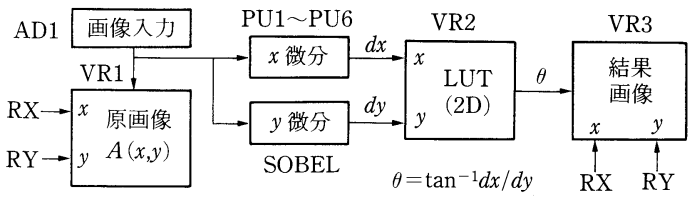

図 10 前処理の実行
に後処理を実行する。

プログラムは 80 ビットの水平型インストラクショ ンで, 演算の他に, 2 枚の画像メモリーの同時読出し と他の画像メモリーへの書込み, 画像メモリーの $x$ アドレスや $y$ アドレスの更新, ループ時の判断分岐 などを 1 命令で同時に実行できる．1命令は 1クロッ ク $(320 \mathrm{~ns})$ で実行される.よって汎用マイクロプロセ ッサと比較して高速処理が可能である.

\section{3 インプリメントと実験}

4.1 節で述べた処理はフレームレートで実行され る. 前処理をPUアレイで実行し, 他の処理はすべて MPUで実行する。

図 10 に, 前処理の実行時のPUアレイの設定をブ ロック図で示す．各ブロックはさらに PU の内部構成 まで細分化されて設定される。第1フィールドでは， 画像入力と同時に PUによる前処理が行われ, 結果が 画像メモリー 3 に, 原画像が画像メモリー 1 にそれぞ れ格納される、第 2 フィールドでは，画像メモリー 3 がMPUにて読出され処理され, 処理結果は画像メモ リー1(原画像)に重ね書きされる。

各処理毎の処理時間を表 1 に示す。前処理時間が 1 フィールド時間 $(16.7 \mathrm{~ms})$ より短いのは, 有効画面 (240ライン) のみ処理するからである. 画像入力開始 から $33.3 \mathrm{~ms}$ 後には処理結果は出力されており, ス ループットの高さはひとつの特徵である.

実験は，高速道路を走行しながら収録したVTRテ ープを用いて行った。 カメラは助手席に設置し, 広角 
表 1 各処理の処理時間

\begin{tabular}{|c|c|c|}
\hline 処 理 & \multicolumn{2}{|c|}{ 処理時間 (ms) } \\
\hline \multirow{2}{*}{ 前処理 } & 15.2 & 15,2 \\
\hline & 0.5 & \multirow{5}{*}{$\begin{array}{c}18.1 \\
\text { (MPU 処理) }\end{array}$} \\
\hline 画面振動成分の計測 & 1.0 & \\
\hline 候補点探索, 直線適合 & 11.6 & \\
\hline 適応平滑化，検証 & 1.0 & \\
\hline $\begin{array}{c}\text { カーブ度計測, 先行車検出, } \\
\text { 表示処理, その他 }\end{array}$ & 4.0 & \\
\hline 合 計 & \multicolumn{2}{|c|}{33.3} \\
\hline
\end{tabular}

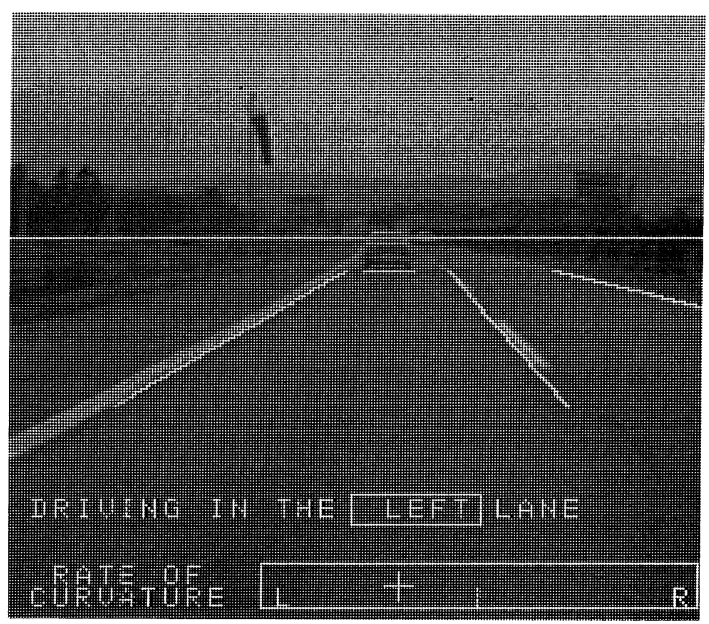

(a)

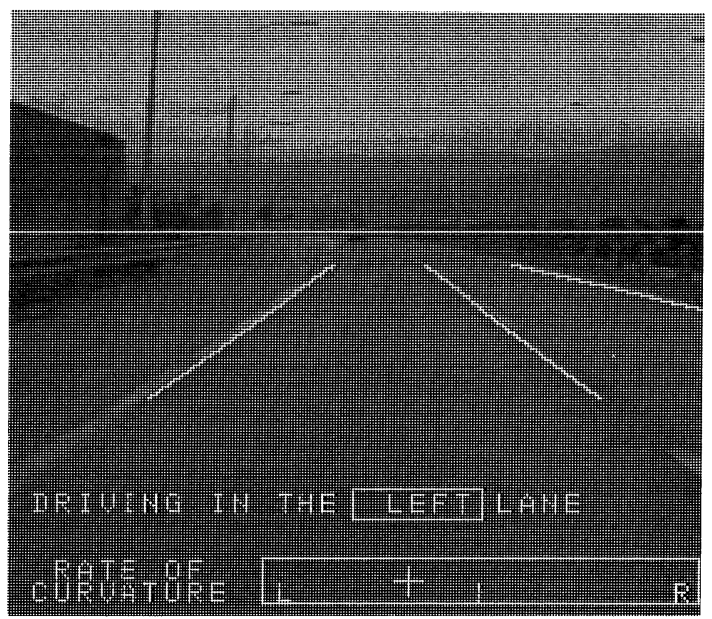

(b)

写真 1 処理結果の例

レンズを用いた。気象条件としては，薄曼りの昼間と いう好条件である。処理結果の表示例を写真 1 に示 す. 写真 1 に扔いては, カーブ度を十字の位置で, 先
行車の位置をアンダーラインで, 白線認識結果と共に 示す.

照明条件の良い限られたシーンにおける実験では， 良好な結果が得られた。より広い条件下で適用可能 な，頑健な処理手法は引き続き課題である。

\section{5.むす び}

自動車用環境認識として，画像処理の役割と課題に ついて論じた。そして，研究事例として高速道路の実 時間白線認識システムを紹介した。

自動車用画像処理の現状は，民生用としての実用化 レベルから考えると，まだ基礎的段階である，屋外で 昼夜天候を問わないという環境下で, 様久な形状をも つ対象物を $100 \%$ で認識するのは現状技術では不可能 といえる. 入力デバイスの課題, 処理アルゴリズム, 処理装置と，課題もまた解決策も多岐にわたる。

画像処理の早期実用化のためには, 画像処理の限界 を見極め，他のセンサとの有機的統合による応用シス テムを研究することもひとつの解決策である。また， 画像処理しやすい道路環境整備や，画像処理を補うた めの通信インフラの整備など, 高知能交通システムに も期待できる。

(1992 年 4 月 1 日受付)

\section{〔参 考 文 献〕}

1）保坂, 谷口: “自動車の知能化”, 計測制御, 30, 1, pp. 46-51 (1991)

2）“自動車の情報化・知能化”, 日経メカニカル，324，pp. 46-84 (1990. 5.28)

3）金出：“米国に扔ける自律移動ロボット研究の動向”, 日本口 ボット学会誌, 5, 5, pp. 376-383 (1987)

4）白井, 大田：“自律移動ロボットに扔けるセンシング技術”, 日本ロボット学会誌, 5, 5, pp. 391-397 (1987)

5）森：“道路環境認識とナビゲーション”, 計測制御, $30,1, \mathrm{pp}$. 21-26 (1991)

6）久田見：“画像認識による自律走行技術”, 自動車技術, 45, 2, pp. 25-31 (1991)

7）倉見：“自動運転技術の開発動向”, 自動車技術, 45, 2, pp. 612 (1991)

8）小沢, 全： “自律走行への視覚応用”, 信学誌, 74, 4 pp. 403408 (1991)

9）八木，川戸：“円錐投影による全方位環境認識”，信学技報, PRU89-46 (1989)

10) J. M. Callahan: "Sight At Night", Automotive Industries, 171, 10 (1991)

11) C. Thorpe, M. H Hebert, T. Kanade, S. A. Shafer : "Vision and Navigation for the Carnegie-Mellon Nablab", IEEE Trans. Pattern Anal. \& Mach. Intell., PAMI10, 3, pp. 362-373 (1988)

12) T. Kanade, A. Gruss, L. R. Carley: "A Very Fast VLSI Rangefinder", Proc. IEEE Int. Conf. on Robotics \& Automation, pp. 1322-1329 (Apr. 1991)

13）塩, スクランスキー: “動画像からの歩行者検出法, 情処学研 資, CV75-5 (1991)

14）浅田：“センサ統合と環境モデルの構築”, 情処学研資, CV64 -8 (1990)

15）全, 桜井, 小林, 小沢：“車両から見た道路像の解析”, 信学論, 
J71-D, 9, pp. 1709-1717（1988）

16）渡辺，金谷：“局所平面近似による道路形状復元”, 情処学研 資, CV62-3 (1989)

17）中嶋, 尾形, 安居院：“道路画像中の物体の奥行きの認識”, 平 3 信学秋季全大, D-263 (1991)

18) F. Ferrari, E. Grosso, G. Sandini, M. Magrassi : "A Stereo Vision System for Real Time Obstacle Avoidance in Unknown Environment", IEEE Int. Workshop on Intell. Robots \& Systems, IROS'90 (1990)

19）鈴木，谷内田：“移動視における対応付けと 3 次元情報の獲 得”, 信学技報, PRU88-88（1988）

20）津戸,八木, 谷内田：“移動視により得られたワイヤーフレー ムモデルからの空間構成の理解”, 情処学研資, CV73-9 (1989)

21）小野田, 渡辺, I. S. Kweon, 久野：“注視点追跡による移動制 御”, 情処学研資, CV73-12 (1989)

22) S. Carlsson, J. O. Eklundh: "Object Detection Using Model Based Prediction and Motion Parallax", Proc. Roundtable Discussion on Vision-Based Vehicle Guidance '90, 5 (1990)

23) V. Graefe, K. D. Kuhnert: "A High Speed Image Process- ing System Utilized in Autonomous Vehicle Guidance", IAPR workshop on CV, pp. 10-13 (1988)

24）榎並，八木：“映像信号の汎用リアルタイム処理”，テレビ誌 43, 12, pp. 1314-1319 (1989)

25）江尻：“マシンビジョン技術：その過去・現在・未来”,第 5 回 産業における画像センシング技術シンポジウム講論集，pp. 121-131 (1990)

26）農宗, 小沢：“高速道路走行画像からの実時間レーンマーカ 検出”, 信学論, J74-D-II, 5, pp. 662-666 (1991)

27）農宗, 芥川：機能可変構造可変型パイプラインプロセッサを もつ高速画像処理装置”, 電学論 C，112-C，2，pp. 81-88 (1992)

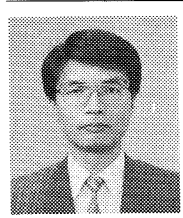

のうそう が゙のり

農宗千典 昭和 52 年, 東京農工大学工 学部電子工学科卒業. 54 年, 同大学院修士 課程修了。同年, 日産自動車(株)入社. 現 在, 同社総合研究所基礎研究所主任研究員. 画像処理に関するソフト・ハードの研究に従 事.

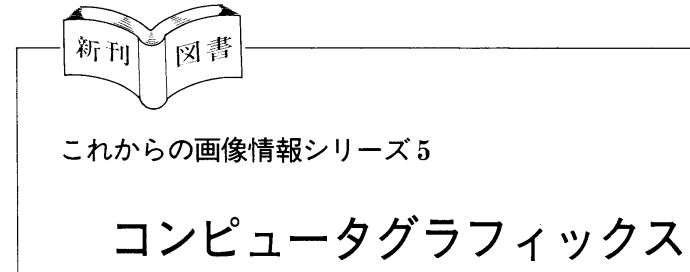

\section{安居院猛・中嶋正之 共著}

コンピュータグラフィックス $(\mathrm{CG})$ は, 1960 年代頃か ら研究が始められ，そのハード，ソフトは共にめざまし い進展を遂げている。コンピュータとグラフィックス周 辺装置を用いて画像，映像を作成する CG 技術は，ここ 数年の間に新しい手法が提案され，また応用分野も急速 に増加し, 機械, 建築, 医学, 教育, 芸術, 娛楽など幅 広く活用されている。この CG の進展に既刊の著書では もはやカバーしきれず, 新しい CG 解説書が望まれてい た. 本書は, CGの基礎的な生成手法から，最新の応用 分野, 今後の展望にいたるまで, CGの初心者から CG を活用する人々を対象に平易に解説している.

本書は 11 章から構成されており，1章では CGの発
展経過について紹介し，2～5 章では CG の基礎につい て, 2 次元, 3 次元の映像生成手法を難しい計算式を少 なめに解説している. 6〜 8 章では最近の CGのレンダ リング手法の中からより現実感のある手法にテーマを絞 って紹介している．9１0 章では近年研究が盛んに行わ れるようになった自然物体や人間の $\mathrm{CG}$ 表現の手法につ いて解説している. 11 章では, CGの最近の話題として 人工現実感や 3 次元通信, CGによるインタフェースな どを紹介し，将来の動向について触れている．

このように本書は, CGの基本技術から応用分野まで を網羅しているので, $\mathrm{CG}$ 全般を学ぶのに役立つ参考書 となっている。特に $\mathrm{CG}$ 生成の新しい手法について，そ の研究成果を積極的に解説しており，大いに読みごたえ がある、また，各章の章末に参考文献が多く紹介されて いるので, さらに深く研究していきたい人々にとっても 有効であろう.

\section{紹介 山内結子 $(\mathrm{NHK})$}

昭晃堂刊（1992 年 7 月 15 日発行), A 5 版, 200 頁, 定価 4,841 円（税込） 